\title{
SOLID-PHASE SYNTHESIS OF OXATHIOCORALINE BY A KEY INTEMOLECULAR DISULFIDE DIMER
}

\author{
Judit Tulla-Puche, Núria Bayó-Puxan, Juan A. Moreno, Andrés M. \\ Francesch, Carmen Cuevas, Mercedes Álvarez, and Fernando Albericio \\ Institute for Research in Biomedicine, Barcelona Science Park, 08028-Barcelona \\ (Spain) \\ PharmaMar, S.A.U., 28770-Colmenar Viejo, Madrid (Spain) \\ Laboratory of Organic Chemistry, Faculty of Pharmacy, University of Barcelona, \\ 08028-Barcelona (Spain) \\ Department of Organic Chemistry, University of Barcelona, 08028-Barcelona \\ (Spain)
}

\section{SUPPLEMENTARY INFORMATION}

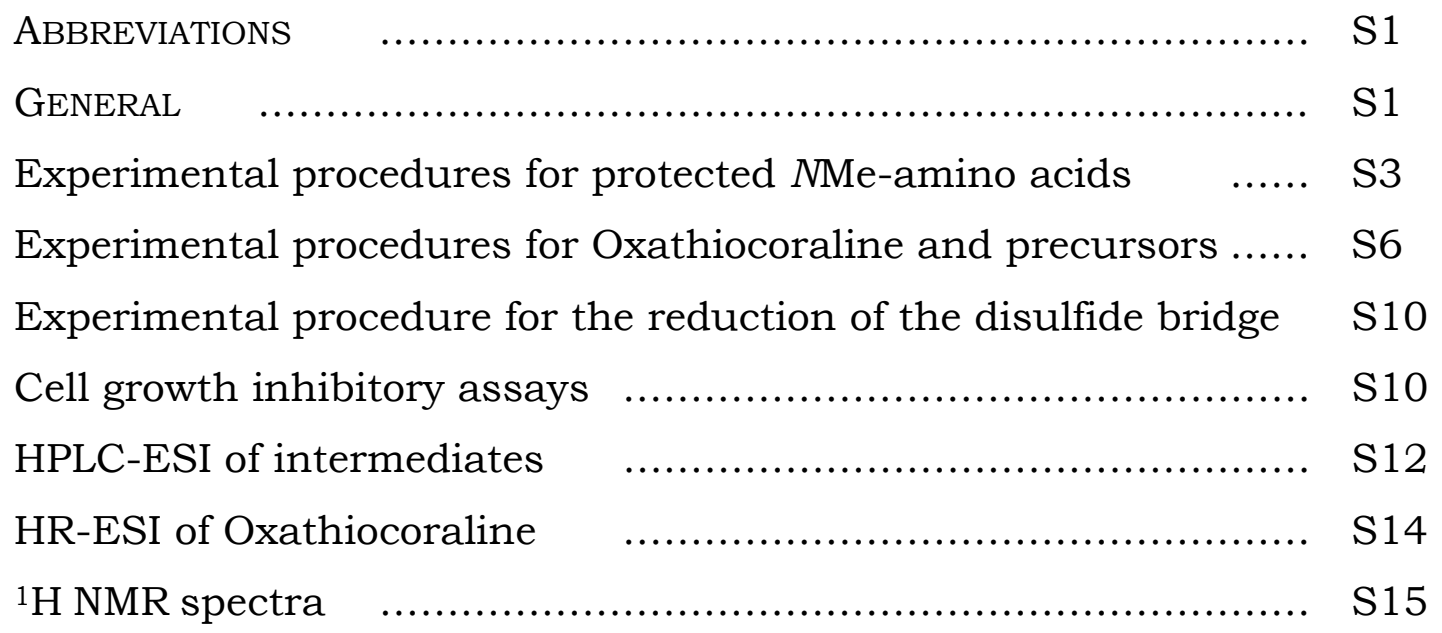




\section{ABBREVIATIONS}

Abbreviations used for amino acids and the designations of peptides follow the rules of the IUPAC-IUB Commission of Biochemical Nomenclature in J. Biol. Chem. 1982, 247, 977-983. The following additional abbreviations are used: ACN, acetonitrile; Alloc, allyloxycarbonyl; Boc, $t$-butyloxycarbonyl; CTC, chlorotrityl chloride (Barlos) resin; DIEA, $N, N$-diisopropylethylamine; $\operatorname{DIPCDI}, \quad N, N$ diisopropylcarbodiimide; DTT, dithiothreitol; DKP, diketopiperazine; DMAP, 4-( $N, N$-dimethylamino)pyridine; DMF, $N, N$-dimethylformamide; EDC.HCl， 1-[3-(dimethylaminopropyl]-3-ethylcarbodiimide; ESMS, electrospray mass spectrometry; HATU, 1-[bis(dimethylamino)methylene]-1H-1,2,3-triazolo-[4,5-b]pyridinium hexafluorophosphate 3-oxide; HOAt, 1-hydroxy-7-azabenzotriazole(3hydroxy-3H-1,2,3-triazolo-[4,5- $b]$ pyridine); HOSu, $N$-hydroxysuccinimide; HPLC, high performance liquid chromatography; MS, mass spectrometry; MSNT, 1-(2-mesitylenesulfonyl)-3-nitro-1H-1,2,4-triazole; pNZ, p-nitrobenzyloxycarbonyl; PyBOP, benzotriazol-1-yl-oxytris (pyrrolidino) phosphonium hexafluorophosphate; TFA, trifluoroacetic acid; TIS, triisopropylsilane; Trt, trityl. Amino acid symbols denote L-configuration unless indicated otherwise. All reported solvent ratios are expressed as $\mathrm{v} / \mathrm{v}$, unless otherwise stated.

\section{GENERAL}

General methods: Protected amino acid derivatives, PyBOP, were obtained from Applied Biosystems (Framingham, MA), Bachem (Bubendorf, Switzerland), Albatross (Montreal, Canada), and NovaBiochem (Läufelfingen, Switzerland). Wang resin was obtained from Novabiochem (Läufelfingen, Switzerland). DIEA, DIPCDI, piperidine, TFA, 
ammonia, iodomethane, allyl chloroformate, and p-nitrobenzyl chloroformate, were obtained from Aldrich (Milwaukee, WI), and EDC $\cdot \mathrm{HCl}$ and HOAt were from Luxembourg Industries (Tel Aviv, Israel). DMF, $\mathrm{CH}_{2} \mathrm{Cl}_{2}$, Acetonitrile (HPLC grade), methanol (HPLC grade), Dioxane, $\mathrm{Et}_{2} \mathrm{O}$, TBME ( $t$-butyl methyl ether) and EtOAc (ethyl acetate) were obtained from SDS (Peypin, France). (R)(-)-thiazolidine-4-carboxylic acid, trifluoromethanesulfonic acid, $N$-hidroxyacetamide methyl and $\mathrm{N}$-hidroxysuccinimide were obtained from Fluka (Buchs, Switzerland). All commercial reagents and solvents were used as received with the exception of DMF and $\mathrm{CH}_{2} \mathrm{Cl}_{2}$, which were bubbled with nitrogen to remove volatile contaminants (DMF) and stored over activated $4 \AA$ molecular sieves (Merck, Darmstadt, Germany), and THF which was distilled from sodium/benzophenone.

Solution reactions were performed in round-bottomed flasks. Organic solvent extracts were dried over anhydrous $\mathrm{MgSO}_{4}$, followed by solvent removal under reduced pressure at temperatures below $40{ }^{\circ} \mathrm{C}$.

Solid-phase syntheses were performed in polypropylene syringes $(2,5$ $\mathrm{mL}$ ) fitted with a polyethylene porous disc. Solvents and soluble reagents were removed by suction. Removal of the Fmoc group was carried out with piperidine-DMF $(1: 4, \mathrm{v} / \mathrm{v})(1 \times 1 \mathrm{~min}, 2 \times 5 \mathrm{~min})$. Washings between deprotection, coupling, and final deprotection steps were carried out with DMF $(5 \times 1 \mathrm{~min})$ and $\mathrm{CH}_{2} \mathrm{Cl}_{2}(5 \times 1 \mathrm{~min})$ using $5 \mathrm{~mL}$ solvent.g- ${ }^{1}$ resin for each wash. Peptide synthesis transformations and washes were performed at $25^{\circ} \mathrm{C}$.

HPLC columns (Symmetry ${ }^{\circledR}$ C18 reversed-phase analytical column, 5.0 $\mu \mathrm{m} \times 4.6 \mathrm{~mm} \times 150 \mathrm{~mm}$ and Symmetry ${ }^{\circledR}$ C18 reversed-phase semipreparative column, $5.0 \mu \mathrm{m} \times 7.8 \mathrm{~mm} \times 100 \mathrm{~mm}$ ) were obtained from 
Waters (Ireland). Analytical HPLC was carried out on a Waters instrument comprising a separation module (Waters 2695), automatic injector, photodiode array detector (Waters 996), and system controller (Millenium ${ }^{32}$ login). UV detection was at 220 and $254 \mathrm{~nm}$, and linear gradients of $\mathrm{CH}_{3} \mathrm{CN}(+0.036 \% \mathrm{TFA})$ into $\mathrm{H}_{2} \mathrm{O}(+0.045 \% \mathrm{TFA})$, were run at $1.0 \mathrm{~mL} \cdot \mathrm{min}^{-1}$ flow rate over $15 \mathrm{~min}$. Semi-preparative HPLC was carried out on a Waters instrument comprising a separation module (Waters 1525 binary pump), automatic injector, and a dual absorbance detector (Waters 2487). UV detection was at 220 and $254 \mathrm{~nm}$, and linear gradients of $\mathrm{CH}_{3} \mathrm{CN}(+0.036 \% \mathrm{TFA})$ into $\mathrm{H}_{2} \mathrm{O}(+0.045 \% \mathrm{TFA})$, were run at $3.0 \mathrm{~mL} \cdot \mathrm{min}^{-1}$ flow rate in the conditions specified for each case.

MALDI-TOF and ES(+)-MS analyses of peptide samples were performed on an Applied Biosystems VoyagerDE RP, using using $\mathrm{ACH}$ matrix, and in a Waters Micromass ZQ spectrometer and in an Agilent Ion Trap 1100 Series LC/MSDTrap. ${ }^{1} \mathrm{H}$ NMR (400 MHz) and ${ }^{13} \mathrm{C}$ NMR (100 MHz) spectroscopy was performed on a Varian Mercury 400. Chemical shifts

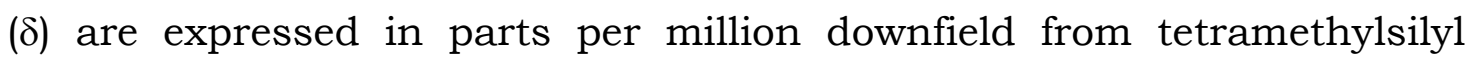
chloride. Coupling constants are expressed in Hertz.

\section{Boc-NMe-Cys(Me)-OH}

$\mathrm{HCl} \cdot \mathrm{H}-\mathrm{NMe}-\mathrm{Cys}-\mathrm{OH}(4.1 \mathrm{~g}, 23.8 \mathrm{mmol})$, obtained from (R)(-)-thiazolidine4-carboxylic acid according to Liu, J-F.; Tang, X-X.; Jiang, B. (Synthesis 2002, 1499-1501), was dissolved in $\mathrm{H}_{2} \mathrm{O}-\mathrm{THF}(1: 1)(170 \mathrm{~mL})$ and the mixture was cooled down to $4{ }^{\circ} \mathrm{C}$. Iodomethane $(2.07 \mathrm{~mL}, 33.3 \mathrm{mmol})$ dissolved in THF (68 mL) and $\mathrm{NaHCO}_{3}(5.3 \mathrm{~g}, 71.4 \mathrm{mmol})$ in $\mathrm{H}_{2} \mathrm{O}(68 \mathrm{~mL})$ were added sequentially dropwise to the amino acid solution. After the addition was complete, the mixture was stirred at $25^{\circ} \mathrm{C}$ for $4 \mathrm{~h}$, at which point the Ellman's test was negative. The solution was acidified until $\mathrm{pH}$ 5 and the solvent was removed under reduced pressure. The residue 
was dissolved in $2 \%$ aqueous $\mathrm{Na}_{2} \mathrm{CO}_{3}$-dioxane $(1: 1)(80 \mathrm{~mL})$ and the solution was cooled down to $4{ }^{\circ} \mathrm{C}$. (Boc) ${ }_{2} \mathrm{O}(6.2 \mathrm{~g}, 35.7 \mathrm{mmol})$ dissolved in 1,4-dioxane $(8 \mathrm{~mL})$ was added to the amino acid solution, and the $\mathrm{pH}$ was adjusted to 8.5-9.5 by adding $10 \%$ aqueous $\mathrm{Na}_{2} \mathrm{CO}_{3}$. The mixture was stirred at $4{ }^{\circ} \mathrm{C}$ for $2 \mathrm{~h}$ and at $25^{\circ} \mathrm{C}$ for 2 days, keeping the $\mathrm{pH}$ at 8.59.5. 1,4-dioxane was removed and the aqueous solution was washed with TBME $(3 \times 50 \mathrm{~mL})$. The aqueous layer was acidified with $4 \mathrm{~N} \mathrm{HCl}$ until $\mathrm{pH} 2$ and the product was extracted with EtOAc $(3 \times 50 \mathrm{~mL})$ and was purified by preparative HPLC (linear gradient from 15 to $50 \%$ ACN over $30 \mathrm{~min}, 40 \mathrm{~mL} / \mathrm{min})$. Obtained: $2.57 \mathrm{~g}, 44 \%$ yield. ${ }^{1} \mathrm{H} \mathrm{NMR}\left(\mathrm{CDCl}_{3}\right.$, $400 \mathrm{MHz}): \delta 7.18(\mathrm{br} s, 1 \mathrm{H}, \mathrm{NH}), 4.74\left(\mathrm{dd}, 1 \mathrm{H}, \mathrm{CH}^{\alpha}\right), 3.05\left(\mathrm{~d}, 1 \mathrm{H}, \mathrm{CH}^{\beta}\right)$, $2.88\left(\mathrm{~d}, 1 \mathrm{H}, \mathrm{CH}^{\beta}\right), 2.84(\mathrm{~s}, 3 \mathrm{H}, N \mathrm{Me}), 2.13\left(\mathrm{~s}, 3 \mathrm{H}, \mathrm{SCH}_{3}\right), 1.46\left(\mathrm{~s}, 9 \mathrm{H}, \mathrm{CH}_{3}\right.$ Boc). ${ }^{13} \mathrm{C} \mathrm{NMR}\left(\mathrm{CDCl}_{3}, 125 \mathrm{MHz}\right): \delta 175.2,156.5,80.7,58.0,33.2,32.1$, 28.6, 15.6. ESMS: $m / z$ calcd for $\mathrm{C}_{10} \mathrm{H}_{19} \mathrm{NO}_{4} \mathrm{~S}, 249.10$; found, $250.3[\mathrm{M}+$ $\mathrm{H}]^{+}$.

\section{Alloc-NMe-Cys(Me)-OH}

In a $500 \mathrm{~mL}$ round-bottomed flask Boc-NMe-Cys(Me)-OH (3.0 g, 12.0 mmol) was reacted with TFA- $\mathrm{CH}_{2} \mathrm{Cl}_{2}(1: 1)$ for $1 \mathrm{~h}$. The mixture was evaporated to dryness and coevaporations with dioxane were carried out in order to remove the excess of TFA. The solid was dissolved in a $30 \%$ aqueous $\mathrm{Na}_{2} \mathrm{CO}_{3}$ solution (50 mL). Next, a solution of allyl chloroformate $(1.5 \mathrm{~mL}, 14.4 \mathrm{mmol})$ in dioxane $(50 \mathrm{~mL})$ was added dropwise, and the $\mathrm{pH}$ was maintained at $8-9$ by the addition of $10 \%$ aqueous $\mathrm{Na}_{2} \mathrm{CO}_{3}$. The course of the reaction was followed by TLC [EtOAc- $\mathrm{H}_{2} \mathrm{O}-\mathrm{AcOH}-2$ propanol $(2: 1: 1: 1)]$. After completion of the reaction, the aqueous phase was washed with TBME $(3 \times 50 \mathrm{~mL})$ and was then acidified to $\mathrm{pH} 2$ by the addition of $4 \mathrm{~N} \mathrm{HCl}$, and the title product was extracted with EtOAc $(3 \times 50 \mathrm{~mL}),(2.5 \mathrm{~g}, 89.6 \%$ yield $) .{ }^{1} \mathrm{H} \mathrm{NMR}\left(\mathrm{CDCl}_{3}, 400 \mathrm{MHz}\right)$ major conformer: $\delta 5.93(\mathrm{~m}, 1 \mathrm{H}, \mathrm{CH}$ Alloc), 5.35 (dd, 1H, CHH' Alloc), 5.22 (dd, 
1H, CHH' Alloc), 4.88 (m, 1H, $\mathrm{CH}^{\alpha}$ ), 4.65 (d, 2H, $\mathrm{CH}_{2}$ Alloc), 3.12 (dd, 1H, $\mathrm{CH}^{\beta}$ ), 2.95 (s, 3H, NMe), $2.92\left(\mathrm{dd}, 1 \mathrm{H}, \mathrm{CH}^{\beta}\right), 2.15$ (s, 3H, $\left.\mathrm{SCH}_{3}\right) .{ }^{13} \mathrm{C} \mathrm{NMR}$ $\left(\mathrm{CDCl}_{3}, 125 \mathrm{MHz}\right): \delta 174.8,157.2,136.8,117.9,67.1,66.9,58.8,33.1$, 32.0, 17.9. ESMS: $m / z$ calcd for $\mathrm{C}_{9} \mathrm{H}_{15} \mathrm{NO}_{4} \mathrm{~S}, 233.07$; found, $234.3[\mathrm{M}+$ $\mathrm{H}]^{+}$.

\section{Boc-NMe-Cys(Acm)-OH}

$\mathrm{HCl} \cdot \mathrm{H}-\mathrm{NMe}-\mathrm{Cys}-\mathrm{OH}(4.1 \mathrm{~g}, 23.8 \mathrm{mmol})$, obtained from (R)(-)-thiazolidine4-carboxylic acid according to Liu, J-F.; Tang, X-X.; Jiang, B. (Synthesis 2002, 1499-1501), was dissolved in $\mathrm{H}_{2} \mathrm{O}$ (12.3 $\left.\mathrm{mL}\right)$ and the solution was purged with Ar, then $N$-hydroxymethylacetamide $(3.54 \mathrm{~g}, 39.7 \mathrm{mmol})$ was added to solution and the mixture was cooled down to $4{ }^{\circ} \mathrm{C}$ under Ar. A solution of TFA in trifluoromethanesulfonic acid (95:5) (41 mL) was added to the amino acid solution. The mixture was stirred at $25^{\circ} \mathrm{C}$ for 16 $h$ until Ellman's test was negative. The product was dissolved in $2 \%$ aqueous $\mathrm{Na}_{2} \mathrm{CO}_{3}$-dioxane $(1: 1)(80 \mathrm{~mL})$ and cooled down to $4{ }^{\circ} \mathrm{C}$. (Boc) ${ }_{2} \mathrm{O}$ (6.2 $\mathrm{g}, 35.7 \mathrm{mmol})$ dissolved in 1,4-dioxane $(8 \mathrm{~mL})$ was added to the amino acid solution, and the $\mathrm{pH}$ was adjusted to $8.5-9.5$ by adding $10 \%$ aqueous $\mathrm{Na}_{2} \mathrm{CO}_{3}$. The mixture was stirred at $4{ }^{\circ} \mathrm{C}$ for $2 \mathrm{~h}$ and at $25{ }^{\circ} \mathrm{C}$ for 3 days, keeping the $\mathrm{pH}$ at 8.5-9.5. 1,4-dioxane was evaporated and the aqueous solution was washed with TBME $(3 \times 50 \mathrm{~mL})$. The aqueous layer was acidified with $\mathrm{HCl}$ until $\mathrm{pH} 2$ and the product was extracted with EtOAc $(3 \times 50 \mathrm{~mL})$. The solvent was removed under reduced pressure to give $1.23 \mathrm{~g}, 16.9 \%$ overall yield). ${ }^{1} \mathrm{H}$ NMR $\left(\mathrm{CDCl}_{3}, 400 \mathrm{MHz}\right): \delta$ 6.72 (br s, 1H, NH), $4.92\left(\mathrm{~m}, 1 \mathrm{H}, \mathrm{CHH}^{\prime} \mathrm{Acm}\right), 4.56\left(\mathrm{~m}, 1 \mathrm{H}, \mathrm{CH}^{\alpha}\right), 4.21(\mathrm{~m}$, $\left.1 \mathrm{H}, \mathrm{CHH} \mathrm{H}^{\prime} \mathrm{Acm}\right), 3.21\left(\mathrm{~m}, 1 \mathrm{H}, \mathrm{CH}^{\beta}\right), 2.89 \& 2.82\left(\mathrm{~m}, 4 \mathrm{H}, \mathrm{CH}^{\beta}\right.$ \& $\left.N \mathrm{Me}\right)$, 2.05 (m, 3H, $\left.\mathrm{CH}_{3} \mathrm{Acm}\right), 1.50$ (s, 9H, $\left.\mathrm{CH}_{3} \mathrm{Boc}\right) .{ }^{13} \mathrm{C} \mathrm{NMR}\left(\mathrm{CDCl}_{3}, 125\right.$ $\mathrm{MHz}): \delta$ 172.6, 159.1, 153.5, 80.9, 59.3, 40.6, 32.3, 31.4, 28.3, 22.9. ESMS: $m / z$ calcd for $\mathrm{C}_{12} \mathrm{H}_{22} \mathrm{~N}_{2} \mathrm{O}_{5} \mathrm{~S}, 306.12$; found, $306.67[\mathrm{M}+\mathrm{H}]^{+}$. 


\section{\{[pNZ-D-Ser(\&)-Gly-OH][Boc-NMe-Cys(Acm)-NMe-Cys(Me)(\&)]\}}

Wang resin (50 $\mathrm{mg}, 0.93 \mathrm{mmol} / \mathrm{g}$ ) was placed in a $3 \mathrm{~mL}$-polypropylene syringe fitted with a polyethylene filter disc. The resin was then washed with $\mathrm{DMF}(3 \times 1 \mathrm{~min})$ and $\mathrm{CH}_{2} \mathrm{Cl}_{2}(3 \times 1 \mathrm{~min})$. Fmoc-Gly-OH $(110 \mathrm{mg}$, $0.37 \mathrm{mmol})$ was dissolved in $\mathrm{CH}_{2} \mathrm{Cl}_{2}-\mathrm{DMF}(9: 1)$ and DIPCDI $(28.8 \mu \mathrm{L}$, $0.19 \mathrm{mmol}$ ) was added. The mixture was then added to the resin and DMAP $(4.5 \mathrm{mg}, 0.04 \mathrm{mmol})$ in DMF $(0.2 \mathrm{~mL})$ was finally added and the mixture was reacted for $14 \mathrm{~h}$ at $25^{\circ} \mathrm{C}$. The Fmoc-Gly-O-Wang resin was subjected to the following washings/treatments: filtration, $\mathrm{CH}_{2} \mathrm{Cl}_{2}(3 \times 1$ $\mathrm{min}), \operatorname{DMF}(3 \times 1 \mathrm{~min})$, piperidine-DMF (1:4) $(1 \times 1 \mathrm{~min}, 2 \times 5 \mathrm{~min})$. Next, Fmoc-D-Ser(Trt)-OH (76.8 mg, $0.135 \mathrm{mmol})$ was introduced with HATU (51.3 $\mathrm{mg}, 0.135 \mathrm{mmol}$ ) as coupling reagent in DMF in the presence of DIEA $(45.9 \mu \mathrm{L}, 0.27 \mathrm{mmol})$ to the peptide resin. The mixture was stirred for $1 \mathrm{~h}$ and, after filtration, Kaiser test indicated the completion of the coupling reaction. The peptide resin was then washed with DMF $(3 \times 1$ min), $\mathrm{CH}_{2} \mathrm{Cl}_{2}(3 \times 1 \mathrm{~min})$, and treated with piperidine-DMF $(1: 4)(1 \times 1$ min, $2 \times 5 \mathrm{~min}$ ) to remove the Fmoc group. In order to introduce the pNZ group, the resin was treated with $p$-nitrobenzyl chloroformate $(29.1 \mu \mathrm{L}$, $0.135 \mathrm{mmol})$ and DIEA $(229 \mu \mathrm{L}, 1.35 \mathrm{mmol})$ in $\mathrm{CH}_{2} \mathrm{Cl}_{2}$ for $45 \mathrm{~min}$. Removal of the trityl group was accomplished by washings with TFA-TIS- $\mathrm{CH}_{2} \mathrm{Cl}_{2}$ (2:2.5:95.5) until a colorless filtrate was obtained. The peptide-resin was then washed with $\mathrm{CH}_{2} \mathrm{Cl}_{2}(3 \times 1 \mathrm{~min})$ and Alloc-NMeCys(Me)-OH (104.8 mg, $0.45 \mathrm{mmol}$ ) was introduced by reaction with DIPCDI $(69.7 \mu \mathrm{L}, 0.45 \mathrm{mmol})$ and DMAP $(5.5 \mathrm{mg}, 0.045 \mathrm{mmol})$ in $\mathrm{DMF}-\mathrm{CH}_{2} \mathrm{Cl}_{2}$ (1:9) for $14 \mathrm{~h}$ at $25^{\circ} \mathrm{C}$. An aliquot of the resin was cleaved and analyzed by HPLC-ESMS: $m / z$ calcd for $\mathrm{C}_{22} \mathrm{H}_{28} \mathrm{~N}_{4} \mathrm{O}_{11} \mathrm{~S}$ 556.15; found, 556.10. Next, to remove the Alloc group, the peptide-resin was treated with $\mathrm{Pd}\left(\mathrm{PPh}_{3}\right)_{4}(5.2 \mathrm{mg}, 4.5 \mu \mathrm{mol})$ and $\mathrm{PhSiH}_{3}(55.4 \mathrm{mg}, 0.45$ mmol) dissolved in $\mathrm{CH}_{2} \mathrm{Cl}_{2}(4 \times 15 \mathrm{~min})$ under $\mathrm{Ar}$, and was then washed with $\mathrm{CH}_{2} \mathrm{Cl}_{2}(3 \times 1 \mathrm{~min})$. The process was repeated three times and Boc- 
NMe-Cys(Acm)-OH (68.8 mg, $0.225 \mathrm{mmol})$ was introduced with $(85.6 \mathrm{mg}$, $0.225 \mathrm{mmol}$ ), HOAt (30.7 mg, $0.225 \mathrm{mmol}$ ), and DIEA (45.9 $\mu \mathrm{L}, 0.27$ $\mathrm{mmol}$ ) as coupling system. The coupling was repeated once. An aliquot of the resin was cleaved with $\mathrm{TFA}-\mathrm{H}_{2} \mathrm{O}-\mathrm{CH}_{2} \mathrm{Cl}_{2}(15: 5: 80)(0.5 \mathrm{~mL}, 1 \times 20$ min). The title compound was purified by semi-preparative reversed HPLC. Conditions: linear gradient (20\% to 50\%) of $\mathrm{CH}_{3} \mathrm{CN}(0.036 \% \mathrm{TFA})$ into $\mathrm{H}_{2} \mathrm{O}(0.045 \%)$ over $25 \mathrm{~min}$, with a flow rate of $3.0 \mathrm{~mL} / \mathrm{min}\left(t_{\mathrm{R}}=19.1\right.$ min). The final compound was analyzed by HPLC-ESMS $(+) /(-)$ and ${ }^{1} \mathrm{H}$ NMR. HPLC-ESMS: $\mathrm{m} / z$ calcd for $\mathrm{C}_{30} \mathrm{H}_{44} \mathrm{~N}_{6} \mathrm{O}_{13} \mathrm{~S}_{2} 760.2$; found, $762.2[\mathrm{M}$

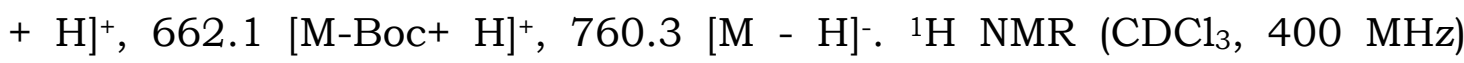
(presence of multiple conformers: $\delta 8.22(\mathrm{~d}, 2 \mathrm{H}$, ar. $\mathrm{CH}$ pNZ), $7.52(\mathrm{~d}, 2 \mathrm{H}$, ar. $\mathrm{CH}$ pNZ), 6.90 (brs, 1H, NH), 6.02 (brs, 1H, NH), 5.45 (brs, NH), 5.35 $\left(\mathrm{m}, 1 \mathrm{H}, \mathrm{CH}^{\alpha}\right), 5.21\left(\mathrm{bd}, 2 \mathrm{H}, \mathrm{CH}_{2} \mathrm{pNZ}\right), 4.77\left(\mathrm{~m}, 1 \mathrm{H}, \mathrm{CH}^{\alpha}\right), 4.49(\mathrm{~m}, 2 \mathrm{H}$, $\mathrm{CH}^{\alpha}$ Gly), $4.21\left(\mathrm{~m}, 1 \mathrm{H}, \mathrm{CH}^{\alpha}\right), 4.10\left(\mathrm{~m}, 1 \mathrm{H}, \mathrm{CH}^{\alpha}\right), 3.10\left(\mathrm{~m}, 2 \mathrm{H}, \mathrm{CH}^{\beta}\right), 2.90$ $\left(\mathrm{m}, 1 \mathrm{H}, \mathrm{CH}^{\beta}\right), 2.78\left(\mathrm{~m}, 2 \mathrm{H}, \mathrm{CH}^{\beta}\right), 2.70$ (brs, 3H, NMe), 2.68 (brs, 3H, NMe), 2.11 (brs, 3H, SMe), 2.10 (s, 3H, CH $\mathrm{CH}_{3} \mathrm{Acm}$ ), 1.51 (s, 9H, Boc).

\section{$\left\{\left[\mathrm{pNZ}-\mathrm{D}-\operatorname{Ser}\left(\&^{1}\right)-\mathrm{Gly}-(\mathrm{Me}) \operatorname{Cys}\left(\&^{2}\right)-(\mathrm{Me}) \operatorname{Cys}(\mathrm{Me}) \&^{3}\right]\left[\mathrm{pNZ}-\mathrm{D}-\operatorname{Ser}\left(\&^{3}\right)-\mathrm{Gly}-\right.\right.$ (Me)Cys $\left.\left.\left(\&^{2}\right)-(\mathrm{Me}) \mathrm{Cys}(\mathrm{Me}) \&^{1}\right]\right\}$}

Formation of the intermolecular disulfide bridge was obtained by treatment of the resin-bound tetrapeptide with $\mathrm{I}_{2}(57 \mathrm{mg}, 0.225 \mathrm{mmol}$, $0.06 \mathrm{M})$ in $\mathrm{DMF}(2 \times 10 \mathrm{~min})$. The resin was repeatedly washed with $\mathrm{CH}_{2} \mathrm{Cl}_{2}(10 \times 1 \mathrm{~min}), \operatorname{DMF}(10 \times 1 \mathrm{~min})$, and $\mathrm{CH}_{2} \mathrm{Cl}_{2}(10 \times 1 \mathrm{~min})$. The dimerized peptide was then cleaved from the resin by treatment with TFA $-\mathrm{H}_{2} \mathrm{O}-\mathrm{CH}_{2} \mathrm{Cl}_{2}(3: 1: 6)(5 \mathrm{~mL}, 2 \times 30 \mathrm{~min})$, and the mixture evaporated with $\mathrm{N}_{2}$, and lyophilized. HPLC-ESMS: $m / z$ calcd for $\mathrm{C}_{48} \mathrm{H}_{60} \mathrm{~N}_{10} \mathrm{O}_{16} \mathrm{~S}_{4}$ 1176.29; found, $1178.10[\mathrm{M}+\mathrm{H}]^{+}$. The dimer was dissolved in $\mathrm{CH}_{2} \mathrm{Cl}_{2}$ and added to a solution of HOAt $(10.1 \mathrm{mg}, 0.07 \mathrm{mmol})$ in $\mathrm{DMF}-\mathrm{CH}_{2} \mathrm{Cl}_{2}$ (1:9), and the mixture was stirred for $30 \mathrm{~min}$. Further addition of PyBOP $(38.7 \mathrm{mg}, 0.07 \mathrm{mmol}$ ) and DIEA $(45 \mu \mathrm{L})$ to adjust to $\mathrm{pH} 8.0$ allowed the 
cyclization reaction to start, which was stirred for $6 \mathrm{~h}$. Then, the solvent was evaporated and the crude bicycle was redissolved in $\mathrm{CH}_{2} \mathrm{Cl}_{2}(50 \mathrm{~mL})$, and washed with $5 \%$ aqueous $\mathrm{NaHCO}_{3}(3 \times 50 \mathrm{~mL})$, and sat. $\mathrm{NH}_{4} \mathrm{Cl}(1 \times$ $50 \mathrm{~mL}$ ), dried $\left(\mathrm{MgSO}_{4}\right)$, and evaporated. An aliquot was purified by semipreparative reversed HPLC. Conditions: linear gradient (37\% to $60 \%)$ of $\mathrm{CH}_{3} \mathrm{CN}(0.036 \% \mathrm{TFA})$ into $\mathrm{H}_{2} \mathrm{O}(0.045 \%)$ over $35 \mathrm{~min}$, with a flow rate of $3.0 \mathrm{~mL} / \mathrm{min}\left(t_{\mathrm{R}}=16.92 \mathrm{~min}\right) .{ }^{1} \mathrm{H} \mathrm{NMR}\left(\mathrm{CDCl}_{3}, 600 \mathrm{MHz}\right): \delta 8.25(\mathrm{~d}, 2 \mathrm{H}$, ar. $\mathrm{CH}$ pNZ), 7.52 (d, 2H, ar. CH pNZ), 6.48 (d, 1H, NH Gly), 5.75 (dd, $1 \mathrm{H}, \mathrm{CH}^{\alpha}$ Cys), 5.66 (d, 1H, NH Ser), 5.31 (bd, 2H, $\mathrm{CH}_{2} \mathrm{pNZ}$ ), 5.05 (t, $\mathrm{CH}$ Gly), $4.71\left(\mathrm{dd}, 1 \mathrm{H}, \mathrm{CH}^{\alpha}\right.$ Cys), $4.59\left(\mathrm{~m}, 1 \mathrm{H}, \mathrm{CH}^{\alpha}\right.$ Ser), $4.52\left(\mathrm{~m}, 1 \mathrm{H}, \mathrm{CH}^{\beta}\right.$ Ser), $4.43\left(\mathrm{~m}, 1 \mathrm{H}, \mathrm{CH}^{\beta}\right.$ Ser), 3.52 (d, 1H, CH Gly), 3.42 (dd, 1H, CH ${ }^{\beta}$ Cys), 3.19 (m, 1H, CH ${ }^{\beta}$ Cys), 3.15 (s, 3H, NMe), 3.07 (m, 2H, $\mathrm{CH}^{\beta}$ Cys), 3.03 (s, $3 \mathrm{H}, \mathrm{NMe}$ ), 2.55 (dd, $\left.1 \mathrm{H}, \mathrm{CH}^{\beta} \mathrm{Cys}\right), 2.47$ (s, 3H, SMe). ${ }^{13} \mathrm{C} \mathrm{NMR}\left(\mathrm{CDCl}_{3}\right.$, $150 \mathrm{MHz}): \delta 172.4(\mathrm{C}=\mathrm{O}), 171.6(\mathrm{C}=\mathrm{O}), 171.4(\mathrm{C}=\mathrm{O}), 170.1(\mathrm{C}=\mathrm{O}), 156.4$ $(\mathrm{C}=\mathrm{O}$ pNZ), 147.6 (ar. C), 145.7 (ar. C), 128.8 (ar. $\mathrm{CH}$ ), 128.8 (ar. $\mathrm{CH}$ ), 124.2 (ar. $\mathrm{CH}), 124.2$ (ar. $\mathrm{CH}) 65.8\left(\mathrm{CH}_{2} \mathrm{pNZ}\right), 64.0\left(\mathrm{CH}^{\beta}\right.$ Ser), $58.9\left(\mathrm{CH}^{\alpha}\right.$ Cys), 52.7 ( $\left.\mathrm{CH}^{\alpha} \mathrm{Cys}\right), 52.6$ ( $\mathrm{CH}^{\alpha}$ Ser), 40.0 (CH Gly), 37.5 ( $\left.\mathrm{CH}^{\beta} \mathrm{Cys}\right), 34.1$ ( $\left.\mathrm{CH}^{\beta} \mathrm{Cys}\right), 31.5(\mathrm{NMe}), 29.9$ (NMe), $16.9(\mathrm{SMe})$.

\section{Oxathiocoraline: $\left\{\left[\mathrm{Hqa}-\mathrm{D}-\mathrm{Ser}\left(8^{1}\right)-\mathrm{Gly}-(\mathrm{Me}) \mathrm{Cys}\left(8^{2}\right)-(\mathrm{Me}) \mathrm{Cys}(\mathrm{Me}) \&^{3}\right][\mathrm{Hqa}\right.$ $\left.\left.-\mathrm{D}-\mathrm{Ser}\left(\approx^{3}\right)-\mathrm{Gly}-(\mathrm{Me}) \mathrm{Cys}\left(\otimes^{2}\right)-(\mathrm{Me}) \mathrm{Cys}(\mathrm{Me}) \approx^{1}\right]\right\}$}

The pNZ-protected bicycle was dissolved in ACN-EtOH- $\mathrm{H}_{2} \mathrm{O}$ (4:1:1) and sodium dithionite $(12.1 \mathrm{mg}, 0.07 \mathrm{mmol})$ was added and the reaction was stirred for $2 \mathrm{~h}$ to obtain the unprotected bicycle. After evaporation of the solvent, the 3-hydroxyquinaldic acid $(10.5 \mathrm{mg}, 0.056 \mathrm{mmol})$ was introduced by reaction with $\mathrm{EDC} \cdot \mathrm{HCl}(10.7 \mathrm{mg}, 0.056 \mathrm{mmol})$, and HOSu (6.4 mg, $0.056 \mathrm{mmol}$ ), in $\mathrm{CH}_{2} \mathrm{Cl}_{2}$ at $25{ }^{\circ} \mathrm{C}$ for 2 days. The solvent was evaporated and the crude product was then purified by analytical HPLC [linear gradient $(50 \%$ to $100 \%)$ of $\mathrm{CH}_{3} \mathrm{CN}(0.036 \% \mathrm{TFA})$ into $\mathrm{H}_{2} \mathrm{O}(0.045 \%)$ over $15 \mathrm{~min}$, with a flow rate of $1.0 \mathrm{~mL} / \mathrm{min} ; t_{\mathrm{R}}=7.9 \mathrm{~min}$ ] to obtain 1.7 
mg (7\% overall yield) of pure oxathiocoraline. HPLC-ESMS: $\mathrm{m} / z$ calcd for $\mathrm{C}_{48} \mathrm{H}_{56} \mathrm{~N}_{10} \mathrm{O}_{14} \mathrm{~S}_{4}$ 1124.29; found, $1125.35[\mathrm{M}+\mathrm{H}]^{+}$. MALDI-TOF: $\mathrm{m} / \mathrm{z}$ calcd for $\mathrm{C}_{48} \mathrm{H}_{56} \mathrm{~N}_{10} \mathrm{O}_{14} \mathrm{~S}_{4}$ 1124.29; found, $1125.99[\mathrm{M}+\mathrm{H}]^{+}$. HR-MS: $m / z$ calcd for $\mathrm{C}_{48} \mathrm{H}_{57} \mathrm{~N}_{10} \mathrm{O}_{14} \mathrm{~S}_{4} 1125.2933[\mathrm{M}+\mathrm{H}]^{+}$, found 1125.2939 . ${ }^{1} \mathrm{H}$ NMR $\left(\mathrm{CDCl}_{3}, 600 \mathrm{MHz}\right): \delta 11.35(\mathrm{~s}, 1 \mathrm{H}, \mathrm{OH}), 8.98(\mathrm{~d}, 1 \mathrm{H}, J=6.4 \mathrm{~Hz}, \mathrm{NH}$ Ser$)$, $7.99(\mathrm{~m}, 1 \mathrm{H}$, ar. $\mathrm{CH}), 7.68(\mathrm{~m}, 1 \mathrm{H}, J=6.9 \mathrm{~Hz}$, ar. $\mathrm{CH}), 7.62(\mathrm{~s}, 1 \mathrm{H}$, ar. $\mathrm{CH}), 7.54$ (m, 2H, ar. CH), 6.54 (d, 1H, $J=7.9 \mathrm{~Hz}, \mathrm{NH}$ Gly), 5.79 (dd, 1H, $J=5.1,10.8 \mathrm{~Hz}, \mathrm{CH}^{\alpha}$ Cys-S), $4.94\left(\mathrm{~m}, 1 \mathrm{H}, \mathrm{CH}^{\alpha} \mathrm{Gly}\right), 4.87$ (m, 1H, $\mathrm{CH}^{\alpha}$ Ser), $4.64\left(\mathrm{~m}, 2 \mathrm{H}, \mathrm{CH}^{\alpha} \mathrm{Cys}(\mathrm{Me}) \& \mathrm{CH}^{\beta} \mathrm{Ser}\right), 4.42\left(\mathrm{dd}, 1 \mathrm{H}, J=5.1 \mathrm{~Hz}, \mathrm{CH}^{\beta}\right.$ Ser), $3.42\left(\mathrm{dd}, 1 \mathrm{H}, J=11.7, \mathrm{CH}^{\alpha}\right.$ Gly), $3.28\left[\mathrm{dd}, 1 \mathrm{H}, J=5.1,11.3, \mathrm{CH}^{\beta}\right.$ Cys(Me)], 3.18 (m, 1H, CH ${ }^{\beta}$ Cys-S), 3.02 (s, 3H, NMe Cys-S), 2.96 [m, 1H, $\mathrm{CH}^{\beta}$ Cys(Me)], 2.85 (m, 2H, CH${ }^{\beta}$ Cys-S), 2.81 [s, 3H, NMe Cys(Me)], 2.17 (s, 3H, SMe). ${ }^{13} \mathrm{C} \mathrm{NMR}\left(\mathrm{CDCl}_{3}\right): \delta 171.8(\mathrm{C}=\mathrm{O}), 171.6(\mathrm{C}=\mathrm{O}), 171.4(\mathrm{C}=\mathrm{O})$, 166.7 (C=O), 152.9 (ar. C), 138.5 (ar. C), 138.1 (ar. C), 130.8 (ar. C), 129.0 (ar. CH), 128.4 (ar. CH), 126.8 (ar. CH), 126.1 (ar. CH), 122.4 (ar. $\mathrm{CH}), 63.7\left(\mathrm{CH}^{\beta}\right.$ Ser), 59.0 ( $\mathrm{CH}^{\alpha}$ Cys), 52.8 ( $\left.\mathrm{CH}^{\alpha} \mathrm{Cys}\right), 51.5\left(\mathrm{CH}^{\alpha} \mathrm{Ser}\right), 39.9$ (CH Gly), 37.1 ( $\mathrm{CH}^{\beta}$ Cys-S), $33.8\left[\mathrm{CH}^{\beta}\right.$ Cys(Me)], 31.2 (NMe Cys-S), 29.8, [NMe Cys(Me)], 15.9 (SMe).

Alternatively, the dimer can be also obtained with the 3-hydroxyquinaldic moiety in place. After washing the pNZ-protected tetrapeptidyl-resin with $\mathrm{DMF}(3 \times 1 \mathrm{~min})$ and $\mathrm{CH}_{2} \mathrm{Cl}_{2}(3 \times 1 \mathrm{~min})$, the $\mathrm{pNZ}$ group was removed by treatment with $6 \mathrm{M} \mathrm{SnCl}_{2}, 1.6 \mathrm{mM} \mathrm{HCl}$ in $\mathrm{DMF}(2$ $\times 30 \mathrm{~min}$ ) and 3-hydroxyquinaldic acid (12.7 $\mathrm{mg}, 0.067 \mathrm{mmol})$ was introduced by reaction with DIPCDI $(10.4 \mu \mathrm{L}, 0.067 \mathrm{mmol})$ and HOAt $(9.1$ $\mathrm{mg}, 0.067 \mathrm{mmol}$ ), in DMF for $90 \mathrm{~min}$. An aliquot of the resin was cleaved and analyzed by HPLC-ESMS: $m / z$ calcd for $\mathrm{C}_{27} \mathrm{H}_{36} \mathrm{~N}_{6} \mathrm{O}_{9} \mathrm{~S}_{2}$ 652.20; found, 652.14. Formation of the intermolecular disulfide bridge was obtained by treatment with $\mathrm{I}_{2}(57 \mathrm{mg}, 0.225 \mathrm{mmol}, 0.06 \mathrm{M}, \mathrm{DMF}),(2 \times 10$ min). The resin was repeatedly washed with $\mathrm{CH}_{2} \mathrm{Cl}_{2}(10 \times 1 \mathrm{~min}), \mathrm{DMF}$ 
$(10 \times 1 \mathrm{~min})$, and $\mathrm{CH}_{2} \mathrm{Cl}_{2}(10 \times 1 \mathrm{~min})$. The dimerized peptide was then cleaved from the resin by treatment with TFA- $\mathrm{H}_{2} \mathrm{O}-\mathrm{CH}_{2} \mathrm{Cl}_{2}$ (3:1:6) (5 mL, $2 \times 30 \mathrm{~min}$ ), and the mixture evaporated with $\mathrm{N}_{2}$, and lyophilized. HPLCESMS: $m / z$ calcd for $\mathrm{C}_{48} \mathrm{H}_{60} \mathrm{~N}_{10} \mathrm{O}_{16} \mathrm{~S}_{4} 1160.31$; found, $1161.84[\mathrm{M}+\mathrm{H}]^{+}$. Cyclization and purification under the conditions described above afforded the pure oxathiocoraline.

\section{Reduction of the Disulfide bridge}

Crude oxathiocoraline $(2.14 \mathrm{mg}, 1.9 \mu \mathrm{mol})$ was dissolved in $6 \mathrm{M} \mathrm{Gdn} \cdot \mathrm{HCl}$, $1 \mathrm{mM}$ EDTA, $0.1 \mathrm{M}$ Tris. $\mathrm{HCl}$ buffer $(1 \mathrm{~mL})$ at $\mathrm{pH} 8.7$ under $\mathrm{N}_{2}$. A $0.38 \mathrm{M}$ dithiothreitol (DTT) solution $(0.5 \mathrm{~mL})$ was added, and the reaction was stirred for $45 \mathrm{~min}$ at $25^{\circ} \mathrm{C}$. The reaction was quantitative as monitored by HPLC and HPLC-ESMS: $m / z$ calcd for $\mathrm{C}_{48} \mathrm{H}_{58} \mathrm{~N}_{10} \mathrm{O}_{14} \mathrm{~S}_{4} 1126.30$, found, $1127.35[\mathrm{M}+\mathrm{H}]^{+}$.

\section{Cell growth inhibition assay}

A colorimetric assay using sulforhodamine B (SRB) was adapted to perform a quantitative measurement of cell growth and viability, following a previously described method. ${ }^{\text { }}$ The cells were seeded in 96well microtiter plates at $5 \times 10^{3}$ cells/well in aliquots of $195 \mu \mathrm{L}$ of RPMI medium and were left to grow in drug-free medium for $18 \mathrm{~h}$ to allow attachment to the plate surface. Samples were then added in aliquots of $5 \mu \mathrm{L}$ (dissolved in DMSO- $\mathrm{H}_{2} \mathrm{O}, 3: 7$ ). After $72 \mathrm{~h}$ exposure, the antitumor

effect was measured by the SRB methodology: cells were fixed by adding $50 \mu \mathrm{L}$ of cold $50 \%$ (wt/vol) trichloroacetic acid (TCA) and were incubated for $60 \mathrm{~min}$ at $4{ }^{\circ} \mathrm{C}$. Plates were washed with deionized $\mathrm{H}_{2} \mathrm{O}$ and dried, and $100 \mu \mathrm{L}$ of SRB solution (0.4\% wt/vol in $1 \%$ acetic acid) was added to each microtiter well and incubated for $10 \mathrm{~min}$ at room temperature. Unbound SRB was removed by washing with $1 \%$ acetic acid. Plates were air-dried, and the bound stain was dissolved with Tris buffer. Optical 
densities were read on an automated spectrophotometer plate reader at a single wavelength of $490 \mathrm{~nm}$. Data analyses were automatically generated by LIMS implementation. Assays were done in a dose-response manner at 10 different concentrations (from $10 \mu \mathrm{g} / \mathrm{mL}$ with 1:2.5 dilutions to $0.0026 \mu \mathrm{g} / \mathrm{mL}$ ). Although concentrations were adjusted in $\mathrm{mg} / \mathrm{mL}, \mathrm{GI}_{50}$ values were calculated in molarity. All assays were run in triplicate, and the curves were automatically adjusted with 30 points by non-linear regression using "Prism 3.03" (GraphPad) software.

\begin{tabular}{|c|c|c|c|c|}
\hline \multicolumn{6}{|c|}{ AT in vitro results (Molar) } \\
\hline \multirow{2}{*}{ Study } & & $\begin{array}{c}\text { Breast } \\
\text { NofCLC(Lung) }\end{array}$ & Colon \\
\hline \multirow{3}{*}{ Kahalalide F } & GI50 & n.d. & $3.99 \mathrm{E}-7$ & $3.25 \mathrm{E}-7$ \\
\cline { 2 - 5 } & TGI & n.d. & $1.35 \mathrm{E}-6$ & $4.40 \mathrm{E}-7$ \\
\cline { 2 - 5 } & LC $_{50}$ & n.d. & $3.18 \mathrm{E}-6$ & $6.16 \mathrm{E}-7$ \\
\hline \multirow{3}{*}{ Oxathiocoraline } & GI50 & $4.62 \mathrm{E}-7$ & $3.11 \mathrm{E}-7$ & $4.00 \mathrm{E}-7$ \\
\cline { 2 - 5 } & TGI & $2.75 \mathrm{E}-6$ & $2.75 \mathrm{E}-6$ & $3.55 \mathrm{E}-6$ \\
\cline { 2 - 5 } & LC50 & $6.40 \mathrm{E}-6$ & $7.91 \mathrm{E}-6$ & $7.55 \mathrm{E}-6$ \\
\hline \multirow{3}{*}{ Thiocoraline } & GI50 & $3.11 \mathrm{E}-9$ & $5.57 \mathrm{E}-9$ & $1.21 \mathrm{E}-8$ \\
\cline { 2 - 5 } & TGI & $2.07 \mathrm{E}-8$ & $2.49 \mathrm{E}-8$ & $2.25 \mathrm{E}-8$ \\
\cline { 2 - 5 } & LC50 & $2.25 \mathrm{E}-7$ & $2.09 \mathrm{E}-7$ & n.d. \\
\hline
\end{tabular}

n.d. means $>2.67 \mathrm{E}-6$

1 (a) Skehan, P.; Storeng, R.; Scudiero, D.; Monks, A.; McMahon, J.; Vistica, D.; Waren, J. T.; Bokesch, H.; Kenney, S.; Boyd, M. R. New colorimetric cytotoxicity assay for anticancer Drug Screening. J. Natl. Cancer Inst., 1990, 82, 1107-1112. (b) Faircloth, G. T.; Stewart, D.; Clement, J. J. A simple screening procedure for the quantitative measurement of cytotoxicity assay. J. Tissue Cult. Methods 1988, 11, 201-205. 


\section{HPLC-ESI of intermediates}
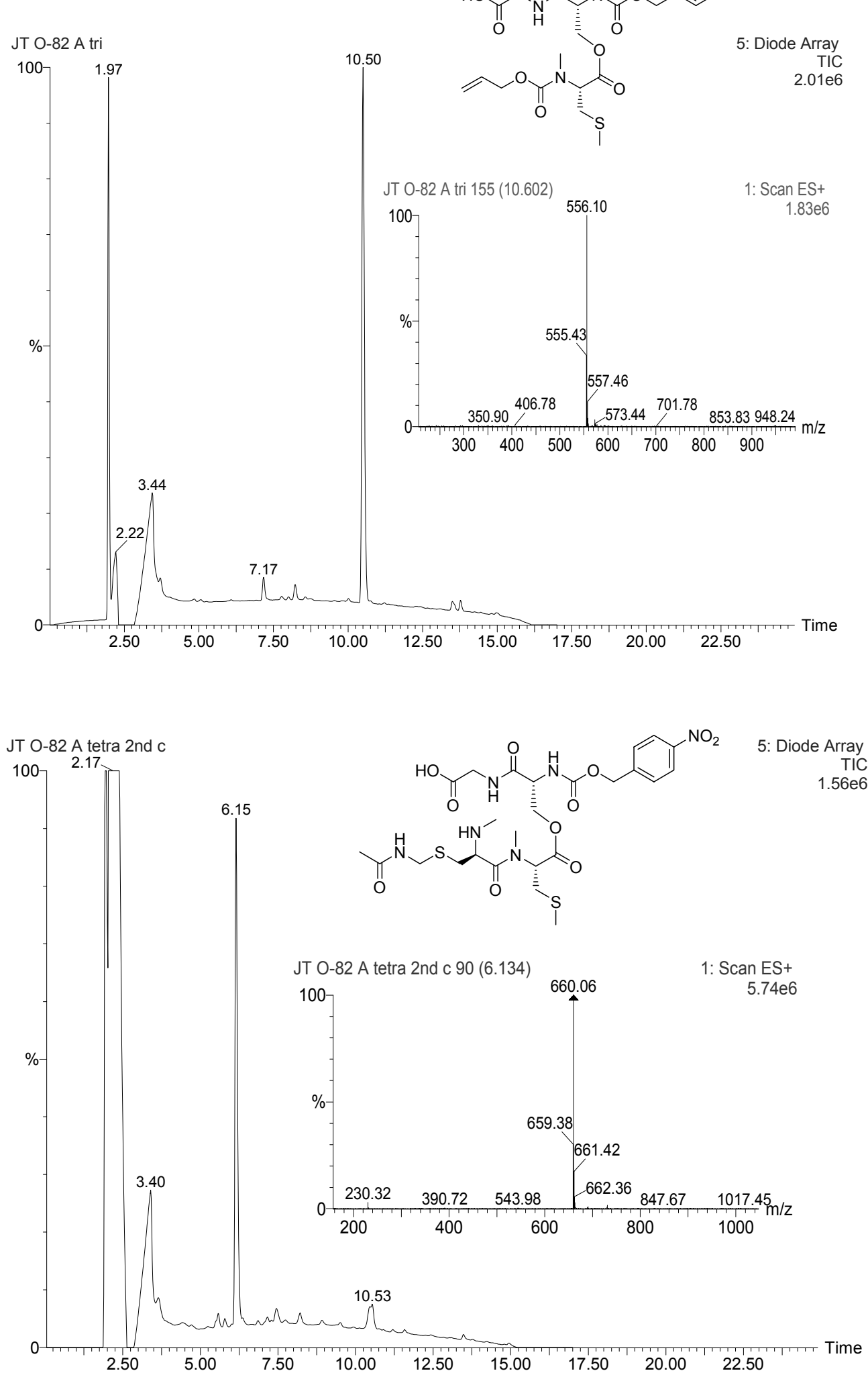

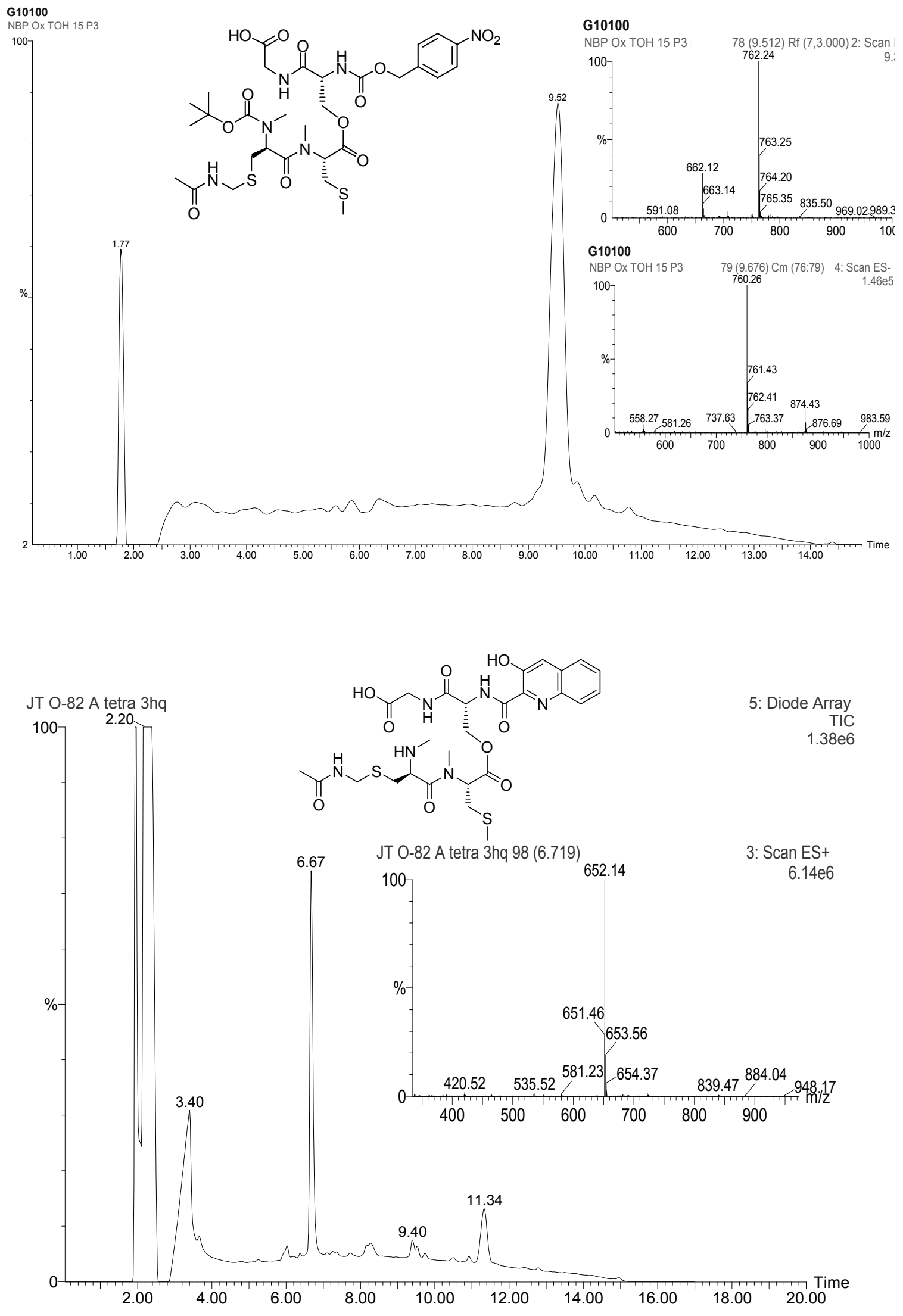


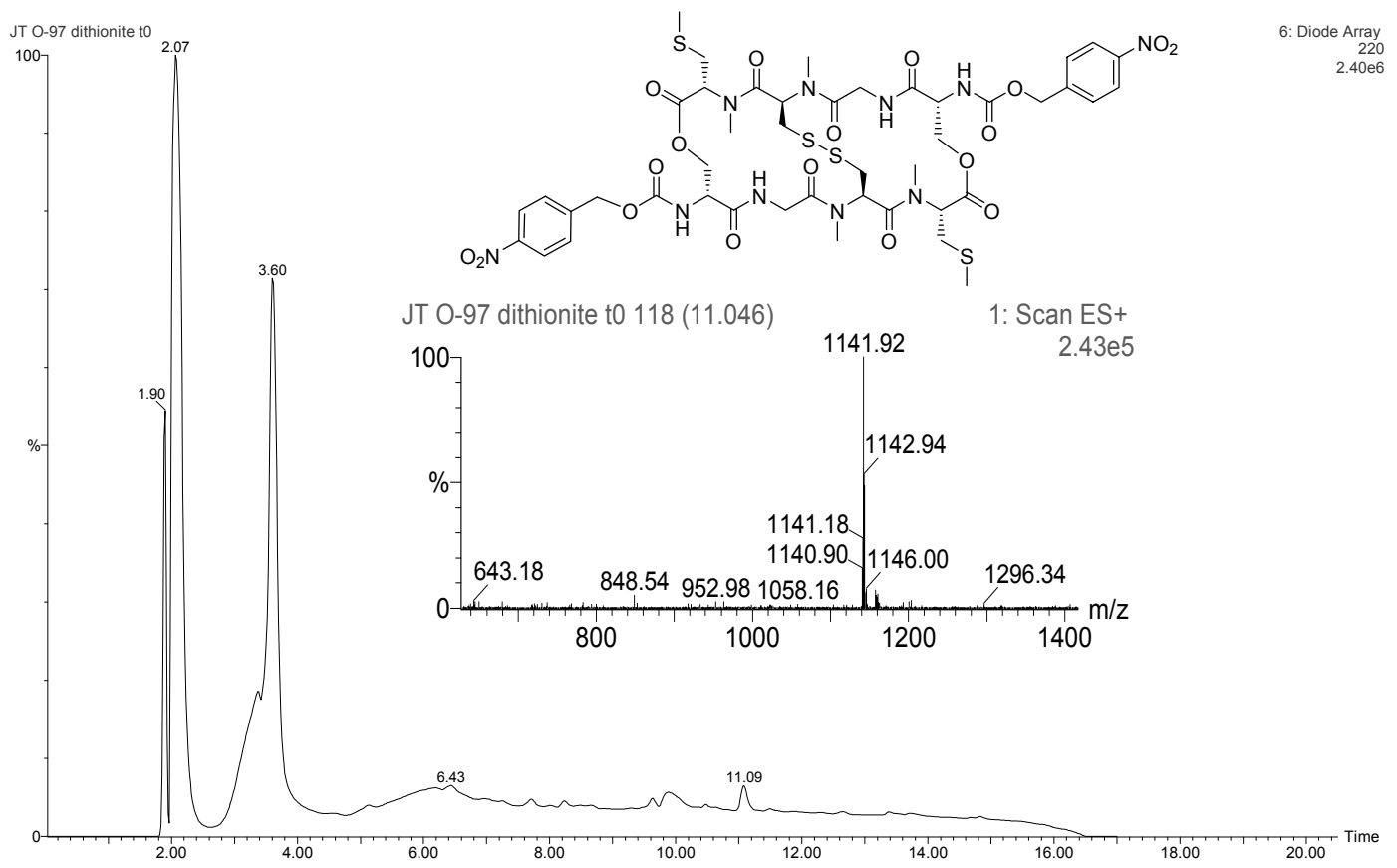

HR-ESI of Oxathiocoraline

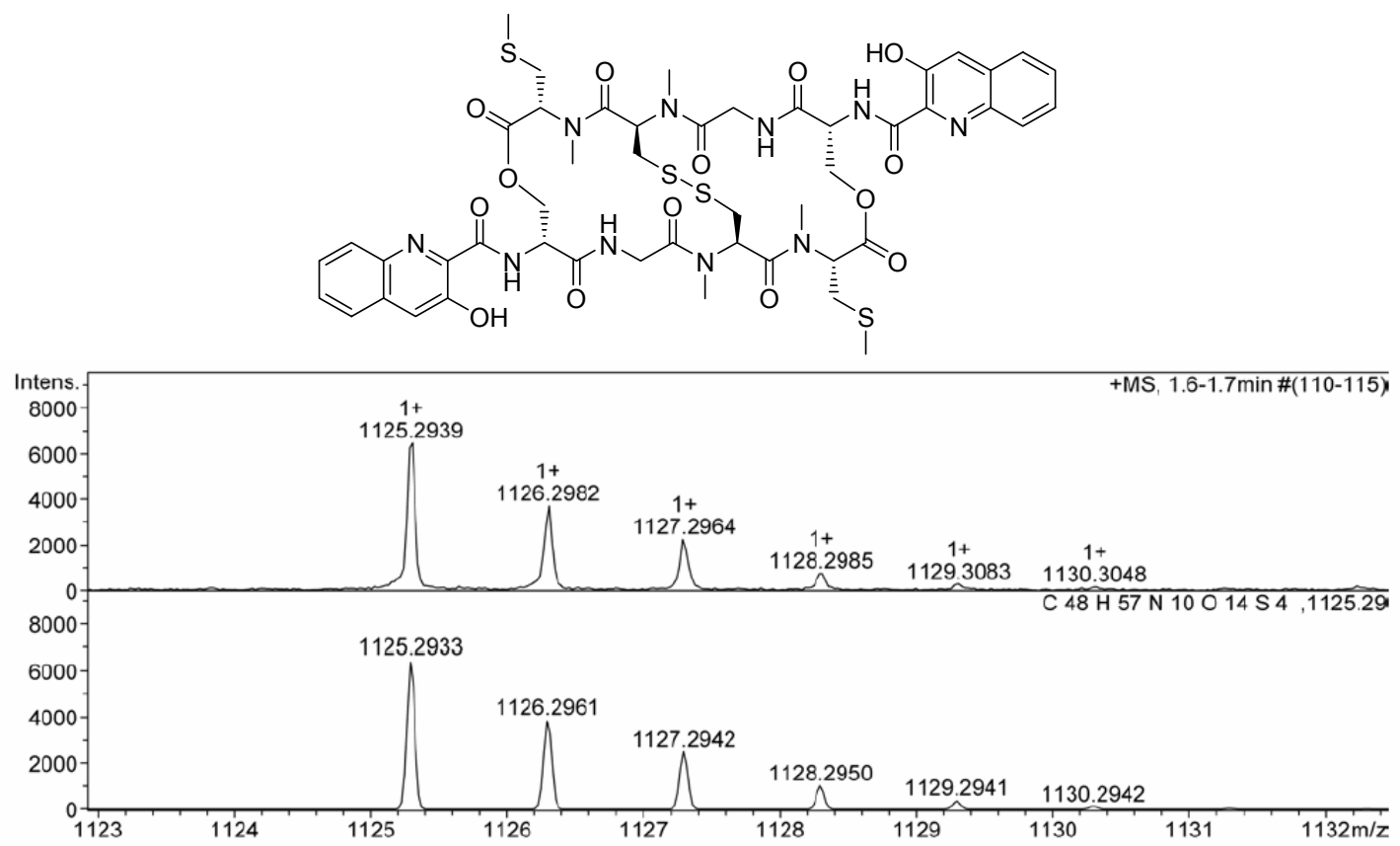




\section{${ }^{1}$ H NMR Spectra}
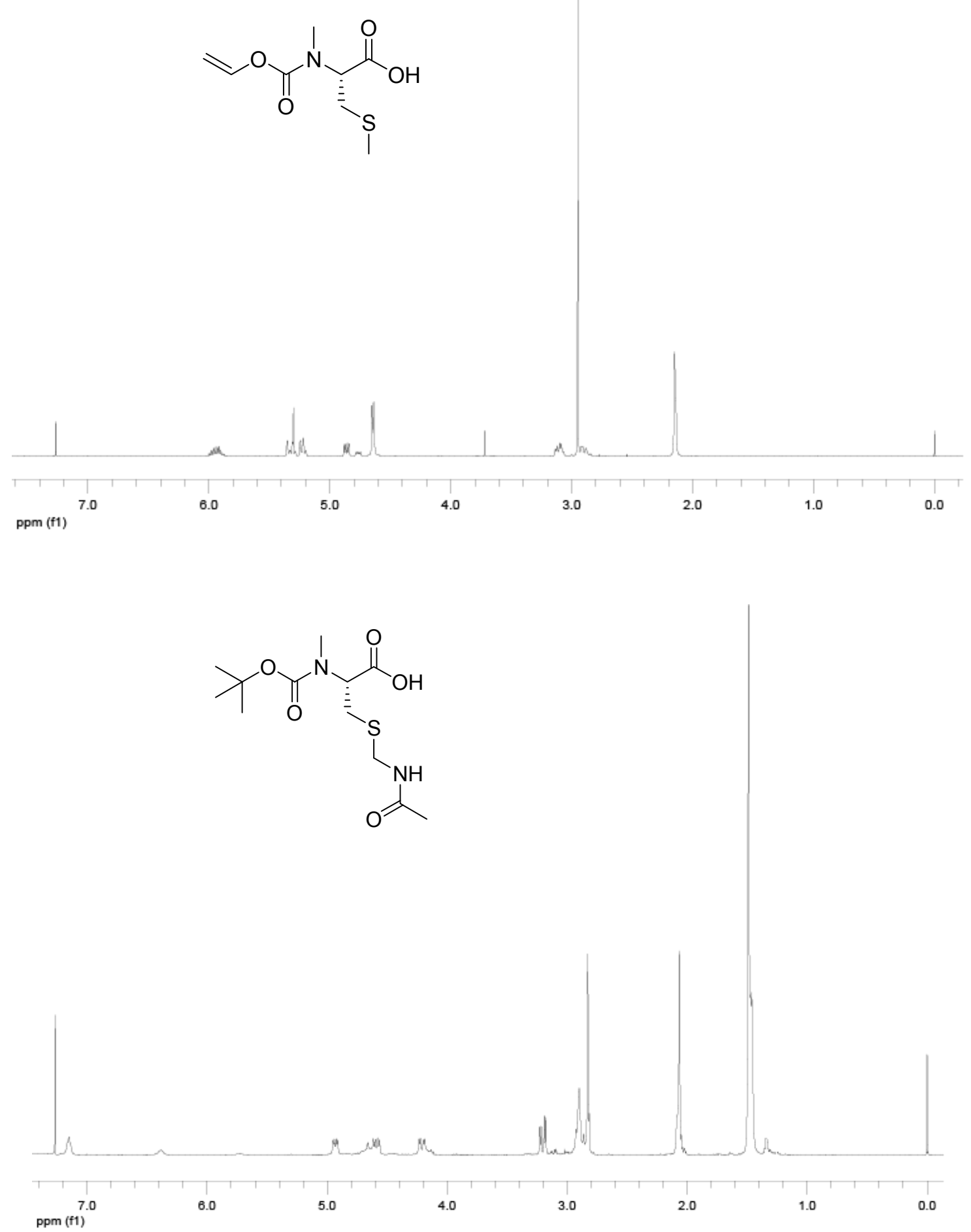

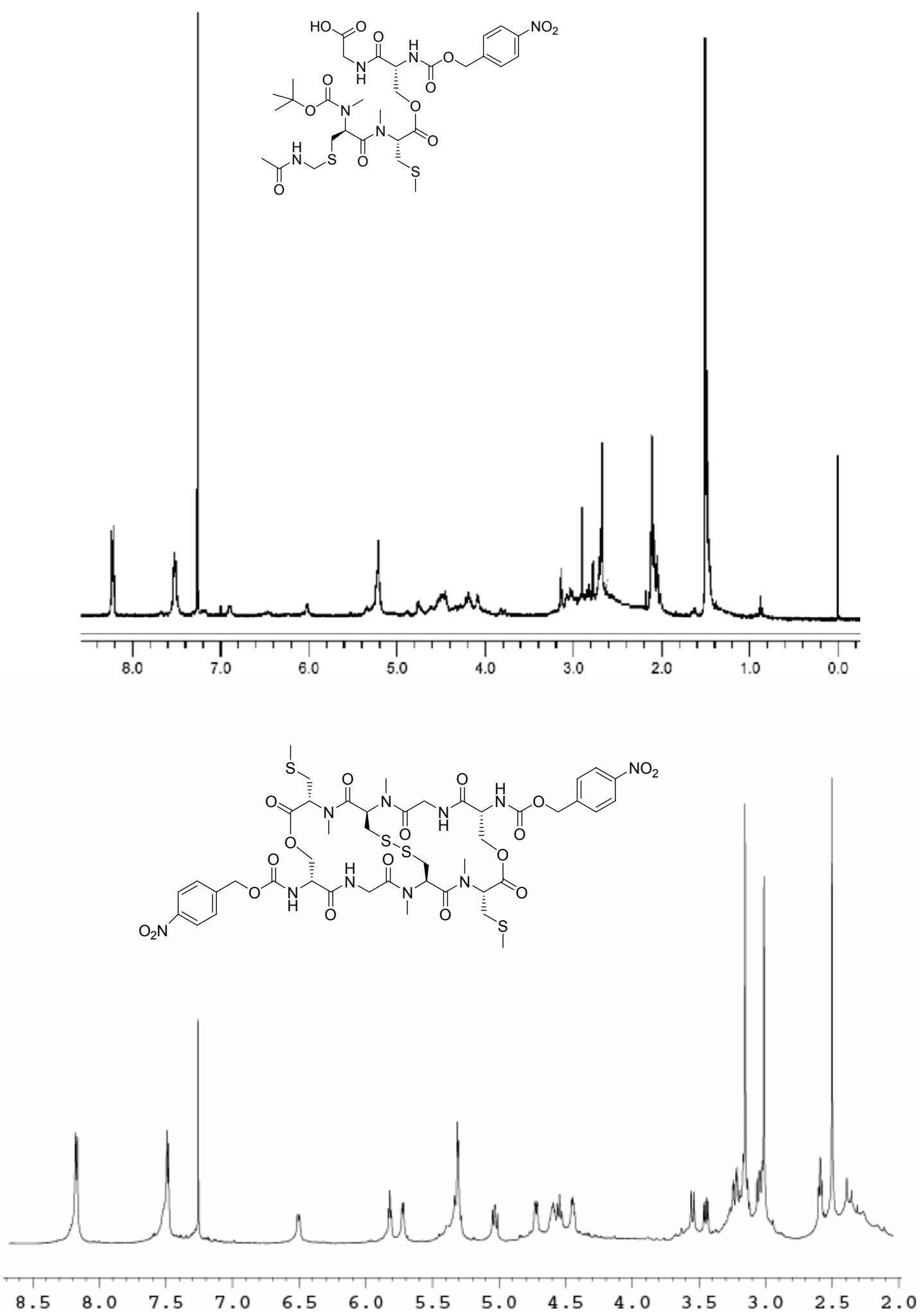


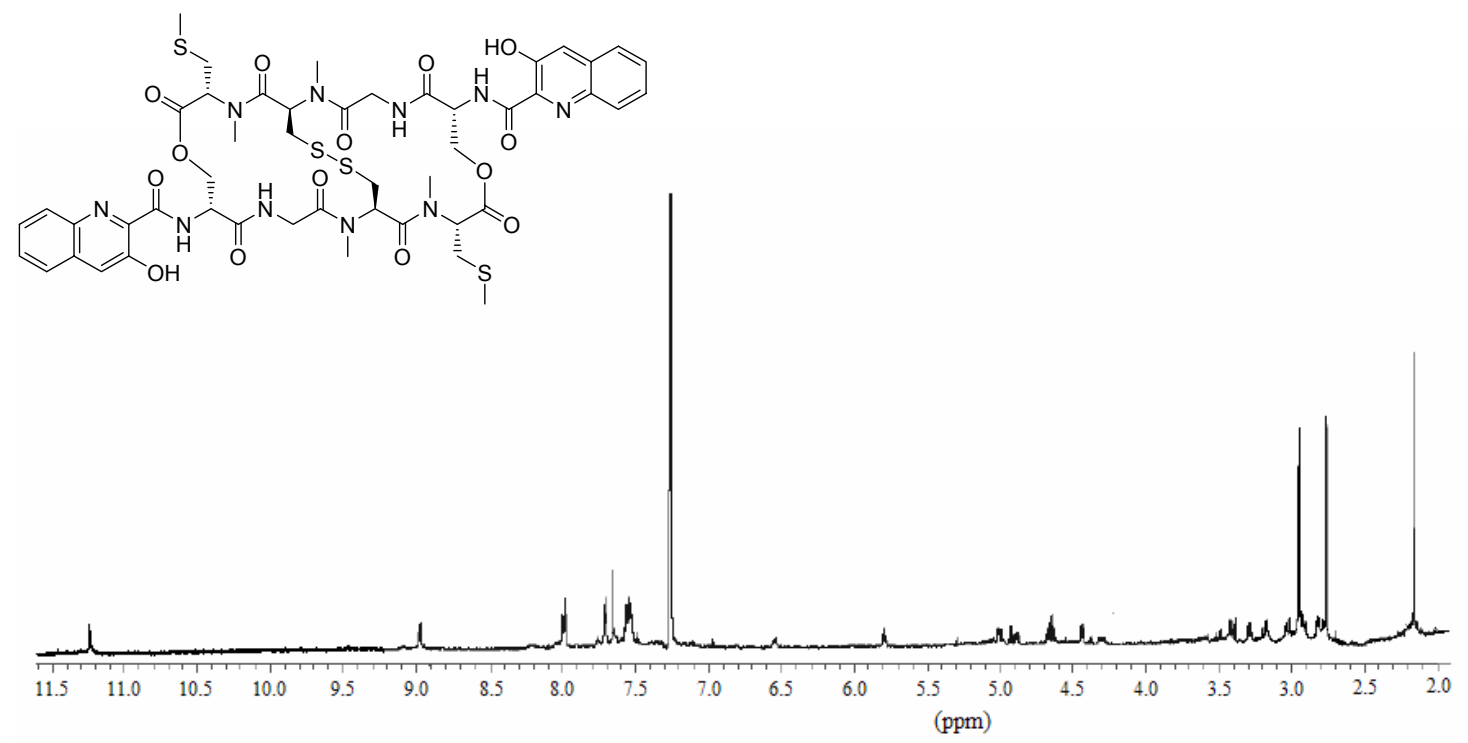

